\title{
PENDIDIKAN AKHLAK DALAM KELUARGA PADA REMAJA DI PASAR LATONG KABUPATEN PADANG LAWAS
}

\author{
Mahadir Muhammad Hsb \\ Program Studi Pendidikan Agama Islam \\ Pascasarjana Institut Agama Islam Negeri Padangsidimpuan \\ Email: mahadirhasibuan@gmail.com
}

\begin{abstract}
Abstrak
Tujuan penelitian ini untuk mengetahui materi pendidikan akhlak, metode dan media pendidikan akhlak. dalam keluarga pada remaja di desa Pasar Latong Kecamatan Lubuk Barumun Kabupaten Padang Lawas. Adapun jenis penelitian ini adalah penelitian kualitatif dengan menggunakan analisis deskriptif dengan sumber data primer dan skunder melalui observasi, wawancara. Hasil penelitian ini menunjukkan materi pendidikan akhlak yang diberikan oleh orang tua pada remaja adalah materi tentang pendidikan akhlak kepada Allah, rasul, dan akhlak kepada manusia baik secara pribadi maupun hubungannya dengan masyarakat dan lingkungan. Metode pendidikan akhlak yang diterapkan adalah keteladanan, kisah alquran dan nabawiyah, targhib dan tarhib, metode mauizah. Sedangkan media pendidikan akhlak yang digunakan yakni media audio, dan media cetak seperti Alquran hadis dan buku-buku agama.
\end{abstract}

Kata Kunci: pendidikan; akhlak; remaja; pasar latong.

\begin{abstract}
The purpose of this study was to determine the material of moral education, methods, and media of moral education. in the family of adolescents in Pasar Latong Village, Lubuk Barumun District, Padang Lawas Regency. The type of this research is qualitative research using descriptive analysis with primary and secondary data sources through observation, interviews. The results of this study indicate that the moral education material given by parents to adolescents is material about moral education to God, apostles, and morals to humans both personally and in relation to society and the environment. The method of moral education applied is exemplary, the story of the Koran and Nabawiyah, targhib and tarhib, the mauizah method. While the moral education media used are audio media, and print media such as the Qur'an, hadith and religious books.
\end{abstract}

Keywords: education; moral; youth; pasar latong.

\section{PENDAHULUAN}

Berhasilnya pendidikan akhlak dalam keluarga dapat dilihat dari seberapa jauh peran orang tua dalam memberikan pendidikan akhlak terhadap keluarga. Meskipun orang tua bekerja, namun tugas utama dalam menanamkan pendidikan akhlak yang baik harus menjadi 
tanggungjawab bagi semua orangtua. Keberhasilan pendidikan akhlak terhadap keluarga selalu disuarakan meskipun banyak tantangan yang dihadapi dalam menyelamatkan keluarga agar terhindar dari api neraka. Peran orang tua dalam mewujudkan generasi Islam yang mantap dalam iman serta memiliki akhlak yang mulia merupakan salah satu tugas mulia dari orang tua. Keluraga yang mampu menjadikan rumah sebagai lembaga pendidikan bagi anaknya maka dengan sendirinya dapat menciptakan keluarga yang memiliki pendidikan yang baik.(Zamroni, 2017)

Seiring dengan pendapat di atas bahwa pentingnya menjaga kelurga agar terhindar dari api neraka yang telah dijanjikan Allah. Pemeliharaan diri dan keluarga dari api neraka harus dilakukan dengan jalan memberi pelajaran dan pendidikan yang baik. Hasil-hasil penelitian yang mengulas tentang pendidikan akhlak sebenarnya bukanlah pertama kali dibahas oleh para peneliti. Namun kajian penelitian tentang akhlak menjadi sangat penting untuk ditelusuri sebagai penambah informasi terhadap generasi Islam saat ini.

Lebih jelasnya, Zamroni dalam hasil penelitiannya menjelaskan bahwa pemberian pendidikan akhlak kepada anggota keluarga di rumah sangatlah penting, agar anak sebagai anggota keluarga dapat memiliki bekal di masa depannya. Proses pendidikan menurutnya harus dilakukan secepat mungkin, sebelum lingkungan yang tidak baik membentuk wataknya yang bersebelahan dengan nilai-nilai ajaran Islam. Perhatian orang tua terhadap pendidikan anaknya sebagai anggota keluarga harus diberikan dengan perhatian yang lebih khusus sehingga anak dapat memperoleh didikan yang maksimal. Jika pendidikan diberikan kepada anggota keluarga maka anggota keluarga justru akan menampilkan akhlak yang mahmudah (baik), dan sebaliknya. Selain itu, dalam mewujudkan keluraga yang berakhlak mulia maka perlu dimiliki strategi atau metode yang tepat guna. Sebagai metode yang tepat, maka metode pembiasaan, metode uswah (mencontohkan perbuatan yang mahmudah), memberikan nasihat serta perhatian yang lebih sepesial merupakan metode atau cara yang paling tepat untuk mewujudkan keluarga yang berakhlak mulia(Zamroni, 2017).

Tuti Alawiyah dalam penelitiannya terhadap pendidikan akhlak dengan mengangkat judul pendidikan akhlak menurut Sa'id Hawwa menghasilkan bahwa pendidikan akhlak yaitu proses pembentukan kepribadian anak secara Islami agar memiliki dasar akhlak yang kokoh dan ilmu pengetahuan yang islami. Bahkan selain itu, dasar-dasar akhlak menurut Sa'id Hawwa adalah adanya loyalitas hanya ditujukan kepada Allah SWT, kepada Rasulullah 
SAW, orang-orang yang beriman, adanya cinta kepada Allah, memiliki karakter lemah lembut terhadap kaum mukminin, dan adanya ketegasan terhadap orang kafir, serta terus berupaya agar tetap memiliki semangat jihad di jalan Allah SWT(Awaliyah \& Nurzaman, 2018).

Uraian di atas memberikan informasi bahwa pendidikan akhlak yang diselenggarakan pada keluarga adalah pendidikan yang pertama dilakukan di lingkungan keluarga dalam pembentukan ketauhidan anak sebagaimana yang telah dijelaskan sebelumnya. Peran orang tua menjadi unsur yang utama bagi tegaknya tauhid dalam keluarga, sehingga setiap orang wajib memiliki tauhid yang baik, sehingga dapat membekali anak-anaknya dengan ketauhidan dan materi-materi yang mendukungnya, di samping anak dapat melihat orang tuanya sebagai teladan yang memberikan pengetahuan sekaligus pengalaman dan pengarahan.

Selanjutnya pendidikan akhlak dalam keluarga merupakan pendidikan utama yang mana disini orang tua sebagai pemeran utamanya. Di dalam sebuah keluarga, orang tua adalah sebagai tokoh idola bagi anak-anaknya, dimana setiap gerak-gerik maupun tingkah laku orang tua selalu mendapat perhatian serius dari anak, bahkan anak-anak lebih cenderung meniru tingkah laku orang tuanya. Kecenderungan manusia untuk meniru, lewat peniruan, menyebabkan ketauladanan menjadi sangat penting artinya dalam proses belajar mengajar atau pendidikan keluarga sikap atau perilaku orang tualah yang akan dicontoh dan ditiru oleh anaknya(Rifa'i, 2019).

Pendidikan keluarga mengajarkan anak akan nilai moral, adab dalam bergaul dengan sesama makhluk Allah, bertetangga, bermasyarakat ataupun bernegara. Ada beberapa metode pendidikan ketika anak dalam kandungan: metode kasih sayang, metode beribadah, metode membaca Alquran, metode pengajian di majelis taklim, metode penghargaan dengan ucapan, metode pemberian hadiah, metode bercerita, metode diskusi, metode tadzkirah, metode mengikut sertakan dengan ucapan, metode do'a, dan metode lagu. Sedangkan pendidikan pasca melahirkan dimulai dari upacara-upacara yang disunatkan agama disaat menerima kelahiran bayi berupa azan, aqiqah, tahnik, tasmiyah, tahliyah/cukur sampai kepada dikhitan, semuanya merujuk kepada pendidikan yang harus diberikan kepada anak di awal pertumbuhannya. Pendidikan ini terus berjalan hingga saatnya anak dicarikan pendamping 
hidupnya/ dinikahkan. Inilah kewajiban orang tua dalam mendidik anak, terutama mendidik akhlak dalam keluarga(Rifa'i, 2019).

Setiap orang tua menginginkan anak-anaknya berkembang secara sempurna. Mereka menginginkan anak yang dilahirkan itu kelak menjadi orang yang sehat, kuat, berketerampilan, cerdas, pandai dan beriman. Dapat dibayangkan betapa pentingnya seorang orang tua bagi seorang anak. Tanpa orang tua mungkin seorang anak akan terlantar, tidak ada yang bertanggung jawab untuk mengasuh dan mendidiknya. Oleh karena itu, kehadiran pendidikan akhlak(Salsabila \& Firdaus, 2018) dalam keluarga harus diprioritaskan sebagai upaya dalam mewujudkan keluarga yang berakhlak yang didasarkan atas nilai-nilai Islam.

Penelitian Zamroni di atas lebih fokus pada bagaimana metode yang tepat dalam pendidikan akhlak melalui metode pembiasaan, metode uswah (mencontohkan perbuatan yang mahmudah), memberikan nasihat serta perhatian yang lebih spesial merupakan metode atau cara yang paling tepat untuk mewujudkan keluarga yang berakhlak mulia. Sementara penelitian yang saya maksudkan pada penelitian ini adalah lebih fokus terhadap bagaimana pendidikan akhlak dalam keluarga pada remaja di desa Pasar Latong kecamatan Lubuk Barumun kabupaten Padang Lawas.

Tuti Alawiyah, dalam hasil penelitiannya hanya mengutarakan bagaimana konsep pendidikan akhlak menurut Said Hawa dengan mengusung thema: pendidikan akhlak menurut Sa'id Hawwa. Sementara dalam penelitian saya hanya memfokuskan pada tema: pendidikan akhlak dalam keluarga pada remaja di desa Pasar Latong kecamatan Lubuk Barumun kabupaten Padang Lawas. Penelitian yang dilakukan oleh Tuti lebih fokus pada telaah pustaka, sementara penelitian yang dilakukan kali ini fokus pada penelitian lapangan dengan melihat fenomena di lapangan.

Selanjutnya, pada penelitian Rif'an telah ditulis dengan judul pendidikan akhlak dalam keluarga. Penelitian ini dilakukan dengan memfokuskannya pada tinjauan normativ dalam Islam. Sedangkan penelitian yang dibahas pada penelitian ini berjudul pendidikan akhlak dalam keluarga pada remaja di desa Pasar Latong kecamatan Lubuk Barumun kabupaten Padang Lawas. Dari dua penelitian ini tentu sangat berbeda, meskipun sama-sama menitikberatkan pada penelitian tentang pendidikan akhlak, namun kedua-duanya berbeda dalam sudut pandang yang dimaksud. Rifan lebih cenderung pada tinjauan normativ menurut 
hukum Islam, sementara pada penelitian ini berfokus pada lapangan yakni meneliti terkait fenomena yang terjadi di desa Pasar Latong.

Krida Salsabila dan Anis Husni Firdaus fokus penelitiannya tertuju pada kajian library atau pustaka. Judul penelitian mereka berdua lebih ditujukan pada tatanan konsep dimana mereka mengusung judul pendidian akhlak menurut Syekh Kholil Bangkalan. Sementara itu, penelitian yang dimaksudkan dalam penelitian ini adalah sebuah penelitian yang mencoba untuk memperoleh informasi dari peristiwa-peristiwa yang terjadi di desa Pasar Latong. Penelitian ini adalah penelitian kualitatif dengan judul pendidikan akhlak dalam keluarga pada Remaja di desa Pasar Latong kecamatan Lubuk Barumun kabupaten Padang Lawas. Dari kedua penelitian ini jelas memiliki persamaan dalam judul secara tematis, namun ketika dilihat dari jenis penelitiannya tentu sangat berbeda antara keduanya.

Berdasarkan semua penelitian yang telah dipaparkan di atas, memang masing-masing dari hasil penelitian ini bisa jadi memiliki sama dalam tema namun berbeda dalam tinjauan, sudut pandang, maupun dalam metode, serta pendekatan yang dilakukan. Dengan demikian, penelitian yang dilakukan pada penelitian kali ini adalah penelitian yang menjadikan desa Pasar Latong sebagai tempat atau lokasi penelitian dengan melakukan penelusuran ke lokasi dengan melihat fenomena-fenoma yang terjadi di desa Pasar Latong.

Desa Pasar Latong merupakan salah satu desa yang terletak di kecamatan Lubuk Barumun kabupaten Padang Lawas. Warga desa ini memiliki keragaman suku yang hidup berbaur dengan mengikuti sistem kehidupan dalihan na tolu. Kehidupan keluarga di Desa Pasar Latong ini mencerminkan kehidupan sa anak sa boru (satu anak satu putri). Artinya setiap keluarga wajib memiiki rasa tanggung jawab terhadap anak-anak yang hidup di desa Pasar latong. Seiring dengan berjalannya waktu, kehidupan pada sistem sa anak sa boru mulai terkikis dengan dengan sifat individualis. Meskipun demikian, orang tua tetap memberikan perhatian terhadap anaknya yaitu dengan jalur pendidikan formal. Desa Pasar Latong jika dilihat dari lembaga pendidikan yang dibangun, paling tidak terdapat lembaga pendidikan baik negeri maupun swasta. Lembaga pendidikan yang terdapat di desa Pasar Latong terdiri dari 2 pondok pesantren, 1 Sekolah Menengah Pertama, 1 Sekolah Menengah Kejuruan Swasta, 1 Sekolah Dasar. Seperti yang telah disebutkan sebelumnya bahwa desa Pasar Latong berada di Kecamatan Lubuk Barumun. 
Desa Pasar Latong jika dilihat dari aktivitas sehari-hari bahwa masyarakatnya berprofesi sebagai petani, perkebun, pedagang. Dengan sulitnya ekonomi, para remaja tidak sedikit yang ikut ambil bagian untuk mencari kehidupan dengan memanen sawit, menanam padi, berkebun, dan memanen padi. Pola hidup seperti ini telah lama dilaksanakan oleh para remaja di Desa Pasar Latong.

Pendidikan yang dilaksanakan pada prinsipnya semua sama, yaitu memberi bimbingan agar dapat hidup mandiri sehingga dapat meneruskan dan melestarikan tradisi yang hidup di masyarakat. Namun yang terjadi justru masih terdapatnya sifat kurang terpuji pada remaja di desa Pasar Latong. Dalam kaitannya dengan tujuan pendidikan nasional sebuah keluarga akan dapat hidup terarah dengan mengikuti aturan-aturan agama maupun atauran pemerintah lewat lembaga pendidikannya. Jika dilihat dari tujuan pendidikan agama antara lain: Membentuk prilaku manusia yang bertaqwa kepada Allah SWT, diperlukan adanya bimbingan, tujuan pendidikan Islam itu adalah mendidik dan mengarahkan manusia kepada jalan Allah SWT, sebab dalam pendidikan mencakup aspek kehidupan manusia di dunia dan di akhirat.

Berdasarkan paparan di atas terlihat bahwa betapa pentingnya didikan orang tua terhadap anak-anaknya. Keluarga merupakan tempat pertama dan utama dalam menanamkan nilai-nilai akhlak pada diri anak. Dalam keluarga terjadi proses saling mempengaruhi antara orang tua dengan anak-anaknya dan antara anak dengan anak lainnya. Oleh sebab itu pergaulan yang berlangsung dalam keluarga harus didasarkan pada akhlak Islami. Oleh karena itu, setiap mukmin wajib menjaga dengan baik keluarganya, keberadaan ibu yang soleh sangat diperlukan, serta seorang ayah yang soleh sehingga keduanya mampu menjaga anak-anaknya dalam menghadapi zaman yang semakin modren.

Pada saat ini banyak pula orang tua yang tidak peduli kepada anak-anaknya. Akibatnya akhlak anak semakin jauh dari ajaran Islam, seperti: tidak menghormati orang tua, berbohong, sering menghabiskan waktu bermain internet, merokok, serta kurangnya sopan santun ketika berbicara dengan orang yang lebih tua.

Menurut pengamatan sementara, sebagian orang tua ada yang mendidik akhlak anaknya dengan bentuk arahan dan memberikan contoh keteladanan, memberikan nasehat kepada anak-anaknya. Hal yang demikian dilakukan dan diupayakan orang tua karena besarnya rasa tanggung jawab mereka akan pentingnya penanaman akhlak pada anaknya. 
Namun pada pengamatan sementara, ada sebagian oang tua hanya menyerahkan anakanaknya ke sekolah tanpa ada upaya yang diberikan, selain karena kesibukan mencari nafkah untuk keluarga juga disebabkan kekurangan pemahaman tentang agama.

\section{METODE PENELITIAN}

Adapun jenis penelitian ini adalah penelitian kualitatif dengan menggunakan analisis deskriptif dengan sumber data primer dan skunder melalui observasi, wawancara. Waktu penelitian ini dimulai sejak bulan Desember 2020 s.d Juni 2021. Penelitian ini dilaksanakan di Desa Pasar Latong Kecamatan Lubuk Barumun Kabupaten Padang Lawas. Sumber data primer adalah sumber data pokok yang diharapkan dalam penelitian secara langsung dari keluarga di Desa Pasar Latong Kecamatan Lubuk Barumun Kabupaten Padang Lawas. Pengambilan sumber data ini dengan menggunakan teknik purposive sampling. Alasan menggunakan teknik purposive sampling adalah karena tidak semua sampel memiliki kriteria yang sesuai dengan fenomena yang diteliti. Oleh karena itu, penulis memilih teknik purposive sampling yang menetapkan pertimbangan-pertimbangan atau kriteria-kriteria tertentu yang harus dipenuhi oleh sumber data primer yang digunakan dalam penelitian ini. Adapun sumber primer dalam penelitian ini yaitu orang tua sebanyak 8 orang dan anak usia remaja berjumlah 8 orang. Sumber data skunder adalah sumber data pelengkap yang diperlukan dalam penelitian ini yaitu data yang dapat menjadi pendukung yang diperoleh dari Kepala Desa, Tokoh Agama, Tokoh Adat.

\section{HASIL DAN PEMBAHASAN}

\section{Hasil}

Penelitian di Desa Pasar Latong Kecamatan Lubuk Barumun Kabupaten Padang Lawas tentang pendidikan akhlak kepada anak-anaknya dapat disimpulkan bahwa: Pertama, Materi pendidikan akhlak dalam keluarga pada remaja di Desa Pasar Latong Kecamatan Lubuk Barumun Kabupaten Padang Lawas memiliki kesesuaian dengan indikator yang telah ditetapkan landasan teori. Hal ini dapat dilihat dengan adanya materi tentang pendidikan akhlak kepada Allah, rasul, dan akhlak kepada manusia baik secara pribadi maupun hubungannya dengan masyarakat dan lingkungan. Sebagai ragam dalam jawaban yang 
mengacu pada indikator dapat dilihat dengan adanya materi seperti akhlak kepada Allah (tawakkal), memohon perlindungan hanya kepada Allah, akhlak kepada rasul (memperingati maulid nabi). Sedangkan indikator akhlak terhadap manusia dapat dilihat dengan adanya sikap hemat, jujur, setia (amanah), adil (menempatkan sesuatu pada tempatnya. Materi akhlak sesama manusia dapat dilihat dari adanya sopan santun, tidak emosi, suka memaafkan, menunjukkan sikap tolong menolong, menamkan rasa persaudaraan. Materi akhlak dengan orang tua dapat dilihat dengan patuhnya anak terhadap orang tua, merendahkan suara di depan orang tua, adanya sikap anak yang suka berterima kasih. Materi akhlak yang diterapkan termasuk adanya pemberian nasehat untuk berbicara dengan baik dan benar, menghormati tetangga, akhlak terhadap waktu (disiplin), akhlak terhadap alam (memelihara alam sama dengan memlihara diri sendiri). Kedua, Metode pendidikan akhlak dalam keluarga pada remaja di Desa Pasar Latong Kecamatan Lubuk Barumun Kabupaten Padang Lawas bahwa metode pendidikan yang diterapkan oleh orang tua semuanya menjawab dengan metode mauizah atau metode nasehat. Di mana masing-masing orang tua menerapkan metode nasehat dalam memberikan pendidikan akhlak terhadap anaknya. Selain itu, sebagai orang tua ada juga yang menerapkan metode metode keteladanan, metode targhib dan tarhib, metode kisah quran dan nabawiyah. Berbeda dengan tokoh masyarakat yang hanya menerapkan metode nasehat semata itupun pada acara besar Islam. Ketiga, Media pendidikan akhlak dalam keluarga pada remaja di Desa Pasar Latong Kecamatan Lubuk Barumun Kabupaten Padang Lawas memiliki jawaban yang beragam. Semua orang tua memberikan jawaban bahwa semuanya menggunakan media berbasis manusia, selebihnya ada yang menerapkan audio dan visual, media cetak seperti Alquran, buku-buku akhlak.

\section{Pembahasan}

Berdasarkan temuan di atas dapat dikaitkan dengan tujuan dari pendidikan akhlak dalam Islam yakni untuk mengantarkan manusia yang sempurna (insan kamil). Al-Ghazali menyebutkan bahwa tujuan pokok dari pendidikan akhlak adalah untuk memperoleh kebahagiaan baik di dunia maupun di akhirat. Tujuan pokok pendidikan akhlak menurut pandangan Al-Ghazali yakni agar manusia memiliki karakter dalam mengasihi, menyayangi, 
pemaaf, penyabar, jujur, ikhlas zuhud. Berkenaan dengan hal ini, jelas bahwa tujuan adanya proses pendidikan akhlak yakni agar dapat menyiarkan agama Islam secara kaffah, mendekatkan diri kepada Allah SWT(Tolchah, 2019).

Imam Al-Ghazali sangat menekankan aspek akhlak dalam sistem pendidikannya karena menurutnya tujuan pendidikan agama adalah pendidikan akhlak itu sendiri. Pendidikan akhlak menurut Imam Al-Ghazali merupakan suatu proses pembentukan manusia yang memiliki jiwa yang suci, kepribadian yang luhur yang bertujuan untuk mendekatkan diri kepada Allah(Sholeh, 2017) .

Imam Al-Ghazali sangat menganjurkan agar dalam pembinaan akhlak anak dilakukan dengan cara latihan-latihan dan pembiasaan-pembiasaan yang sesuai dengan perkembangan jiwa dan akalnya. Hal ini seakan-akan dipaksakan agar anak itu terhindar dari kebiasaan yang menyesatkan. karena pembiasaan dan latihan akan membentuk sikap tertentu pada anak, yang lambat laun sikap itu akan bertambah jelas dan kuat. Akhirnya tidak tergoyahkan karena telah masuk menjadi bagian dari kepribadian. Sehingga Imam Al-Ghazali menyatakan: "jika anak itu tumbuh sudah dibiasakan dibiasakan dan diajari yang baik-baik, maka nantinya ketika ia mencapai usia baligh tentulah ia akan dapat mengetahui rahasianya yakni mengapa perbuatan yang tidak baik itu dilarang oleh ayah. pendidikan akhlak harus diajarkan dalam keluarga agar anggota keluarga terutama anak terhindar dari api neraka, kemudian anak tersebut harus dijaga dari pergaulan yang jahat serta jangan dibiasakan mewah(Sholeh, 2017).

Jadi tujuan dari pendidikan islam itu sendiri adalah terbinanya seluruh potensi manusia seutuhnya baik dia secara jasmani, rohani, materiil, spritual, hati nurani, akal pikiran, bakat, dan lainnya dengan cara memberikan pengetahuan, wawasan, keterampilan, dalam menguasai teknologi, sikap, kepribadian, karakter, secara seimbang sesuai dengan nilai-nilai ajaran Islam. Tujuan pendidikan merupakan untuk meningkatkan kualitas manusia. Yakni, manusia yang beriman dan bertaqwa kepada Tuhan Yang Maha Esa, berbudi pekerti luhur, berkepribadian baik, disiplin, bekerja keras, bertanggung jawab, mandiri, cerdas, dan terampil serta sehat jasmani maupun rohani. Pendidikan, apapun visi dan misinya, harus mampu mencerdaskan kehidupan bangsa dan mengembangkan manusia seutuhnya, tak terkecuali lembaga pendidikan dengan ciri khas Islam yang bernama madrasah. Jadi dapat disimpulkan bahwa tujuan dari pendidikan akhlak yang dimaksud adalah membentukan 
manusia yang memiliki jiwa yang suci, kepribadian yang luhur yang bertujuan untuk mendekatkan diri kepada Allah.

Sejalan dengan pemahaman di atas, maka posisi pendidik sangat dibutuhkan dalam rangka mewujudkan harapan tersebut. Banyak ahli menjelaskan tentang pendidik yang ideal. Istilah pendidik jika dilihat pada kaca mata Islam dapat dijelaskan bahwa pendidik adalah individu maupun kelompok yang memiliki tanggung jawab terhadap perkembangan seluruh potensi yang ada pada peserta didik baik terkait dengan hal kognitif, psikomotorik maupun dalam hal afektifnya harus didasarkan pada nilai-nilai agama Islam(Ali et al., 2014) .

Selain itu, eksistensi seorang ibu sebagai anggota keluarga sekaligus ibu dari anakanak mempunyai peran mengurus rumah tangga, sebagai pendidik utama anak-anaknya, sebagai pelindung dan sebagai anggota kelompok sosial di tempatnya. Selai itu, ibu dapat berperan sebagai pencari nafkah tambahan atas keperluan dalam rumah tangganya. Semtara posisi anak sebagai anggota keluarga harus melaksanakan peran berdasarkan tingkat perkembanganya baik fisik, mental, sosial maupun keagamaannya. Oleh karena itu, keluarga mempunyai peran masing-masing, lingkungannya, keluarganya dalam merealisasikan tugas masing-masing.

Ayah dan ibu adalah orang yang sangat berperan penting dalam pembentukan kepribadian di samping ligkungan dan keluarga. Setiap orang tua dari mulai tukang becak, buruh, nelayan, petani, pedagang, bahkan sampai pegawaipun pasti bercita-cita ingin memiliki anak-anak yang saleh dan sukses dalam kehidupanya, baik dunia maupun akhirat, oleh karena itu ia akan terus mendidik dan mengajarkan anak-anaknya dengan ilmu-ilmu yang dimilikinya dan tak peduli seberapa besar biaya yang dikeluarkan untuk menyekolahkan demi mewujudkan cita-citanya yaitu mencetak anak yang sukses dimasa depan.

Berdasarkan pemahaman di atas M.Quraish Shihab, menjelaskan bahwa kehidupan keluarga, apabila diibaratkan sebagai suatu bangunan, demi terpelihara dari hantaman badai, topan dan goncangan yang dapat meruntuhkannya, memerlukan pondasi yang kuat dan bahan bangunan yang kokoh serta jalinan perekat yang lengket. Pondasi kehidupan keluarga adalah ajaran agama, disertai dengan kesiapan fisik dan mental-mental calon ayah dan ibu. Beliau menambahkan bahwa keluarga merupakan sekolah tempat putra-putri bangsa belajar. Selain 
pendidik, maka materi menempati posisi yang sangat penting dalam pendidikan akhlak remaja di sebuah keluarga.

Materi tersebut adalah yakni materi tentang akhlak terhadap Allah, yang diwujudkan dengan mengenal, mengetahui, mendekati, dan mencintainya, melaksanakan segala perintahnya dan menjauhi segala larangannya menghiasi diri dengan sifat-sifatnya atas dasar kemampuan dan kesanggupan manusia, membumikan ajarannya dalam kehidupan individu, masyarakat dan bangsa.

Kedua, yakni materi tentang iman kepada Rasulullah saw. Maksudnya adalah sebagai ujud dari iman, cinta dan hormat kepada Nabi Muhammad SAW, dan juga sebagai bentuk terima kasih atas jasa-jasa beliau yang dalam mengarahkan umatnya ke jalan yang lurus. Kemudian akhlak sesame manusia dapat dilihat dengan adanya akhlak terhadap diri sendiri, akhlak terhadap sesama manusia, akhlak terhadap orang tua, akhlak dalam masyarakat, sampai akhlak terhadap alam dan waktu. Ada dua hal penting hubungan manusia dengan alam, yaitu manusia sebagai khalifah dan manusia sebagai pengelola alam, manusia sebagai khalifah telah diberikan bekal dan fasilitas oleh Allah SWT yang lengkap untuk mengemban tugas secara kreatif dan dinamis, membawa manusia harus menyeimbangkan pikiran dan kalbunya. Ketimpangan pada salah satunya akan menyebabkan jatuh dari kekhalifahannya.

Berakhlak kepada lingkungan alam adalah menyikapinya dengan cara memelihara hidup dan kelestariannya. Agama Islam menekankan agar manusia mengendalikan dirinya dalam mengeksploitasi alam, sebab alam yang rusak akan dapat merugikan bahkan menghancurkan kehidupan manusia sendiri, untuk itu, seorang muslim dituntut untuk menebarkan rahmat bagi seluruh alam (rahmatan lil alamin), yaitu memandang alam dan lingkungannya dengan rasa kasih sayang.

Selanjutnya, untuk mewujudkan akhlak terhadap remaja dibutuhkan sebuah metode yang tepat. Abdurrahman an-Nahlawi mengatakan metode pendidikan Islam sangat efektif dalam membina akhlak anak didik, bahkan tidak sekedar itu metode pendidikan Islam memberikan motivasi sehingga memungkinkan umat Islam mampu menerima petunjuk Allah. Menurut Abdurrahman an-Nahlawi metode pendidikan Islam adalah metode dialog, metode kisah Qurani dan Nabawi, metode perumpaan Qurani dan Nabawi, metode keteladanan, metode aplikasi dan pengamalan, metode ibrah dan nasihat serta metode targhib dan tarhib(Agus, 2017). 
Di samping itu, Islam mempunyai metode tepat untuk membentuk anak didik berakhlak mulia sesuai dengan ajaran Islam. Dengan metode tersebut memungkinkan umat Islam/ masyarakat Islam mengaplikasikannya dalam dunia pendidikan. Dengan demikian diharapkan akan mampu memberi kontribusi besar terhadap perbaikan akhlak anak didik, untuk memperjelas metode-metode tersebut akan di bahas sebagai berikut (Agus, 2017). Adapun metode yang pertama digunakan dalam memberikan pendidikan kepada anak adalah seperti metode dialog Qurani dan Nabawi. Maksudnya adalah metode menggunakan tanya jawab, apakah pembiacaaan antara dua orang atau lebih, dalam pembicaraan tersebut mempunyai tujuan dan topik pembicaraan tertentu. Metode dialog berusaha menghubungakn pemikiran seseorang dengan orang lain, serta mempunyai manfaat bagi pelaku dan pendengarnya. Kedua metode kisah Qurani dan Nabawi yakni dalam al-Quran banyak ditemui kisah menceritakan kejadian masa lalu, kisah mempunyai daya tarik tersendiri yang tujuannnya mendidik akhlak, kisah-kisah para Nabi dan Rasul sebagai pelajaran berharga. Termasuk kisah umat yang ingkar kepada Allah beserta akibatnya, kisah tentang orang taat dan balasan yang diterimanya. Seperti cerita Habil dan Qobil. Ketiga, yakni metode mauizah menurut Abdurrahman An-Nahlawi dinyatakan bahwa nasihat mempunyai beberapa bentuk dan konsep penting yaitu, pemberian nasehat berupa penjelasan mengenai kebenaran dan kepentingan sesuatu dengan tujuan orang diberi nasehat akan menjauhi maksiat, pemberi nasehat hendaknya menguraikan nasehat yang dapat menggugah perasaan afeksi dan emosi, seperti peringatan melalui kematian peringatan melalui sakit peringatan melalui hari perhitungan amal. Keempat merupakan metode pembiasaan dengan Akhlak Terpuji. Manusia dilahirkan dalam keadaan suci dan bersih, dalam keadaan seperti ini manusia akan mudah menerima kebaikan atau keburukan. Karena pada dasarnya manusia mempunyai potensi untuk menerima kebaikan atau keburukan. kedudukan metode pembiasaan bagi perbaikan dan pembentuakan akhlak melalui pembiasaan, dengan demikian pembiasaan yang dilakukan sejak dini akan berdampak besar terhadap kepribadian/ akhlak anak ketika mereka telah dewasa. Sebab pembiasan yang telah dilakukan sejak kecil akan melekat kuat di ingatan dan menjadi kebiasaan yang tidak dapat dirubah dengan mudah. Dengan demikian metode pembiasaan sangat baik dalam rangka mendidik akhlak anak. Kelima, metode keteladanan menurut Muhammad bin Muhammad al-Hamd mengatakan pendidik itu besar dimata anak didiknya, apa yang dilihat dari gurunya akan ditirunya, karena murid akan meniru dan 
meneladani apa yang dilihat dari gurunya. Dengan demikian keteladanan menjadi penting dalam pendidikan akhlak, keteladanan akan menjadi metode ampuh dalam membina akhlak anak. Mengenai hebatnya keteladanan Allah mengutus Rasul untuk menjadi teladan yang paling baik, Muhammad adalah teladan tertinggi sebagai panutan dalam rangka pembinaan akhlak mulia. Keenam, metode targhib dan tarhib adalah janji yang disertai bujukan dan rayuan untuk menunda kemaslahatan, kelezatan, dan kenikmatan. Sedangkan tarhib adalah ancaman, intimidasi melalui hukuman.

Mengenai media yang digunakan menurut A. Tabrani Rusyan dan Yani Daryani Dijelaskan bahwa, salah upaya yang mesti ditempuh untuk menciptakan suasana pembelajaran yang efektif tidak lain kecuali dengan memberikan suasana yang tenang atau kondusif serta mengerahkan segala upaya atau sumber belajar melalui pengalaman belajar anak dengan menggerakkan belajar secara efektif dan efisiensi(Nurmadiah, 2016).

Istilah "media" jika ditelusuri dalam persfektif bahasa maka terambir dari bahasa latin yang memiliki makna perantara. Berdsarkan istilah inilah maka sering dijumpai ketika orang lain mengatakan media pembelajaran berarti sama maksudnya dengan sarana yang digunakan sebagai alat untuk mengantarkan materi pendidikan. Lembaga (AECT) yang dipanjangkan dengan sebutan Association for Education and Communication Technology mendefinisikan bahwa media adalah setiap bentuk proses penyampaian informasi. Bahkan media dapat diartikulasikan sebuah benda yang dimanipulasikan, di dengar, dilihat dibicarakan bahkan instrument yang dimanfaatkan untuk proses belajar mengajar(Muhammad Hasan Baidlawie, 2018).

Sejalan hal di atas maka maksud media dalam riset ini lebih kepada pendekatan serta pengalaman oleh orang tua atau keluarga dalam memberikan pendidikan kepada anggota keluarga atau remaja. Media yang dimaksudkan dalam hal ini memang bukanlah seperti bentuk video atau gambar serta bentuk tulisan secara nyata, namun yang dimaksudkan media pada penelitian ini termasuk hal-hal seperti keteladan, perintah atau larangan, ganjaran dan hukuman.(Sumiharsonno \& Hasanah, 2017) Dengan demikian media ini lebih banyak konsennya pada penerapan nilai-nilai dari ajaran Islam.

Dilihat dari jenisnya, media dibagi ke dalam media audio, visual dan audiovisual. Media audio adalah media yang hanya mengandalkan kemampuan suara saja, seperti Radio, cassete recorder, piringan hitam. Sedangkan Media visual adalah media yang hanya 
mengandalkan indra pengelihatan. Media visual ini ada yang menampilkan gambar atau simbol yang bergerak seperti film strip (film rangkai), foto, gambar, atau lukisan, cetakan. Adapula media visual yang menampilkan gambar atau simbol yang bergerak seperti film bisu, film kartun. Sedangkan media audiovisual merupakan media yang mempunyai unsur suara dan unsur gambar. Jenis media ini mempunyai kemampuan yang lebih baik karena meliputi kedua jenis media yang pertama dan yang kedua, media audiovisual terdiri atas audiovisual diam, yaitu media yang menampilkan suara dan gambar diam seperti film bingkai suara (sound slides), film rangkai suara. Audiovisual gerak, yaitu media yang dapat menampilkan unsur suara dan gambar yang bergerak seperti film suara dan video cassette.

\section{KESIMPULAN}

Pendidikan akhlak remaja pada keluarga di Desa Pasar Latong dapat dilihat dengan adanya penyampaian materi tentang penguatan kepada ilahi, rasul, sesama manusia, alam, waktu. Pendidikan yang diberikan dengan menggunakan metode mauizah atau metode nasehat, metode metode keteladanan, metode targhib dan tarhib, metode kisah quran dan nabawiyah, metode nasehat semata itupun pada acara besar Islam. Sedangkan media yang digunakan dalam mendidik remaja tetap menggunakan media berbasis manusia, selebihnya ada yang menerapkan audio dan visual, media cetak seperti Alquran, buku-buku akhlak. Saran-saran yang diberikan pertama kepada orang tua di Desa Pasar Latong Kecamatan Lubuk Barumun Kabupaten Padang Lawas agar: a. Jangan hanya mengandalkan kepada guru di Taman Pendidikan Alquran atau guru pesantren, sekolah, guru mengaji saja untuk pendidikan keagamaan, karena akan mengakibatkan anak kurang dalam bersosialisasi dengan kedua orang tuanya.b. Istiqamahlah memberikan contoh atau tauladan yang baik kepada anak karena ketauladanan lebih mudah ditiru oleh anak dan anak juga akan selalu merekam apa yang dilakukan orang tua dari pada hanya memberikan perintah dan pengarahan saja. Saran yang kedua, untuk tokoh agama di Desa Pasar Latong Kecamatan Lubuk Barumun Kabupaten Padang Lawas agar: a. Semua tokoh agama memiliki tugas untuk mengembalikan agama pada posisinya atau mengembalikan peran agama sesuai dengan fungsinya. Maka dari itu perbanyaklah kegiatan agama yang nantinya dapat mencetak tokoh agama baru. b. Para tokoh agama dan pemuka agama masing-masing perlu membina masyarakat agar agama 
dijadikan sebagai landasan diri pribadi dan kelompok untuk bersikap baik terhadap sesama manusia.

\section{REFERENSI}

Agus, Z. (2017). Pendidikan Akhlak Anak Dalam Keluarga Menurut Islam. Raudhah Proud To Be Professionals : Jurnal Tarbiyah Islamiyah, 2(1), 1-20. https://doi.org/10.48094/raudhah.v2i1.11

Ali, M., Pendidik, H., \& Ali, M. (2014). Hakikat Pendidik Dalam Pendidikan Islam. Jurnal Tarbawiyah, 11(Januari-Juli), 82-96.

Awaliyah, T., \& Nurzaman, N. (2018). Konsep Pendidikan Akhlak Menurut Sa'id Hawwa. Jurnal Penelitian Pendidikan Islam, 6(1), 23. https://doi.org/10.36667/jppi.v6i1.152

Muhammad Hasan Baidlawie, B. T. E. S. dan. (2018). Pendidik Dalam Perspektif Pendidikan Islam. AlIkhtibar: Jurnal IImu Pendidikan, 5(1), 652-671. https://doi.org/10.32505/ikhtibar.v5i2.556

Nurmadiah, N. (2016). Media Pendidikan. Al-Afkar : Jurnal Keislaman \& Peradaban, 5(1), 131-144. https://doi.org/10.28944/afkar.v5i1.109

Rifa'i, A. (2019). PENDIDIKAN AKHLAK DALAM KELUARGA (Tinjauan Normatif dalam Islam). AlMadrasah: Jurnal Pendidikan Madrasah Ibtidaiyah, 3(2), 235. https://doi.org/10.35931/am.v0i0.138

Salsabila, K., \& Firdaus, A. H. (2018). Pendidikan Akhlak Menurut Syekh Kholil Bangkalan. Jurnal Penelitian Pendidikan Islam, 6(1), 39. https://doi.org/10.36667/jppi.v6i1.153

Sholeh, S. (2017). Pendidikan Akhlak dalam Lingkungan Keluarga Menurut Imam Ghazali. Jurnal $\begin{array}{llll}\text { Pendidikan Agama Islam } & \text { Al-Thariqah, }\end{array}$ https://doi.org/10.25299/althariqah.2016.vol1(1).618

Sumiharsonno, M. R., \& Hasanah, H. (2017). Media Pembelajaran.pdf. https://books.google.co.id/books?id=VJtIDwAAQBAJ\&pg=PR4\&dp=buku+media+pembelajaran +april+2017\&hl=id\&sa=X\&ved=2ahUKEwjJ16Wp4czsAhVw7XMBHVxwAgsQ6AEwAHoECAMQA $\mathrm{g} \# \mathrm{v}=$ onepage $\& \mathrm{q}=$ buku media pembelajaran $\$ 20$ april $2017 \& \mathrm{f}=\mathrm{false}$ 
Tolchah, M. (2019). Studi Perbandingan Pendidikan Akhlak Perspektif al- Ghazāli dan al-Attas. ElBanat: Jurnal Pemikiran Dan Pendidikan Islam, 9(1), 79-106.

Zamroni, A. (2017). Strategi Pendidikan Akhlak Pada Anak. Sawwa: Jurnal Studi Gender, 12(2), 241. https://doi.org/10.21580/sa.v12i2.1544 